\title{
PROBLEMATIKA HUTANG PADA MASA PANDEMI COVID-19 DI DESA SUKAWANGI
}

\author{
Suud Sarim Karimullah \\ Mahasiswa Magister Ilmu Syariah UIN Sunan Kalijaga Yogyakata \\ Suudsarimkarimullah@gmail.com
}

\author{
Lilyan Eka Mahesti \\ Alumni FEBI UIN Sunan Kalijaga Yogyakarta \\ lilyanmahesti@gmail.com
}

\begin{abstract}
This research will look at how debt problems during the pandemic of Covid-19 in community life in Sukawangi village towards family harmony. This is because debt can be a helper for a family afflicted with economic problems, but on the other hand, debt can also ensnare and torment a family which results in conflicts over the harmony and integrity of the household. This research is a type of field research with the nature of analytic descriptive research, which provides an overview and explanation of the facts of situations, circumstances and social phenomena that occur in the field through an anthropological approach. In this research, data collection methods will be carried out through interviews, observation and analysis of various documentation. The results of this study concluded that the economic dependence of the Sukawangi village community on debt during the pandemic of Covid-19 to survive caused problems in family life. Few people are successful and successful in managing their money from debt by making good economic breakthroughs.
\end{abstract}

Keywords: Debt, Covid-19, Family, Harmony.

\section{PENDAHULUAN}

Dalam setiap kehidupan keluarga ${ }^{1}$ hampir tidak dapat lepas dengan persoalan ekonomi yang berkaitan dengan hutang. Hutang dalam kehidupan keluarga sering dilakukan oleh suami atau istri untuk memenuhi kebutuhan hidup keluarganya yang semakin meningkat. Selain untuk memenuhi kebutuhan keluarga, berhutang juga dilakukan untuk tambahan modal atas usaha yang akan atau sedang dilakukan.

Berhutang bukanlah suatu perbuatan yang buruk dalam kehidupan sosial masyarakat sepanjang yang mempunyai hutang tersebut bisa membayar kembali atas apa yang telah ia hutangi. Persoalan hutang dalam kehidupan keluarga dapat memicu terhadap keharmonisan

\footnotetext{
1 Unit terkecil dalam suatu struktur kehidupan sosial masyarakat yang dibangun atas perkawinan yang berdasarkan hukum dan agama yang terdiri dari suami dan istri serta anak disebut dengan keluarga. Suatu lembaga sosial yang paling kecil atau dasar dalam kehidupan sosial masyarakat yang mempunyai peranan strategis dalam mencetak kulitas manusia juga dapat diartikan sebagai keluarga. Lihat: Mufidah Ch,. 2008. Psikologi Keluarga Islam Berwawasan Gender. (Malang: UIN Press). h. 38-39.
} 
rumah tangga sebagaimana yang terjadi di desa Sukawangi. Desa Sukawangi sendiri terletak di Kecamatan Sukawangi, Kabupaten Bekasi, Provinsi Jawa Barat.

Sesuai dengan pengamatan awal secara langsung, ternyata ditemukan bahwa penduduk di desa Sukawangi banyak yang mempunyai hutang dibeberapa tempat, seperti koperasi, bank plecit, ${ }^{2}$ rentenir, serta bank-bank besar lainnya. Sebelum terjadinya pandemi Covid-19, banyak juga keluarga di desa tersebut yang memiliki hutang. Hutang tersebut dilakukan dengan alasan untuk menambah modal usaha yang nyatanya sudah mendarah daging pada sebagian keluarga di desa Sukawangi. Namun, karena adanya pandemi Covid-19 yang melanda, justru menjadikan banyak masyarakat desa Sukawangi tidak dapat melunasi hutangnya dengan lancar dan baik karena sulitnya mendapatkan penghasilan. Banyak juga yang justru nekat berhutang lantaran terdesak oleh kebutuhan ekonomi dalam keluarga pada masa pandemi Covid-19. Peneliti menemukan di lapangan bahwa selain hari libur kerja setiap harinya pasti terdapat saja rumah-rumah penduduk yang dihampiri oleh penagih hutang.

Hutang yang dipinjam membuat keluarga di Desa Sukawangi mengalami berbagai masalah yang kompleks. Mulai dari masalah terhadap tetangga hingga pada internal keluarga. Banyak terjadi keretakan hubungan rumah tangga di desa tersebut lantaran tekanan untuk membayar hutang namun dengan kemampuan membayar yang sangat minim kerena tidak ada pemasukan keuangan dan sulitnya mendapatkan penghasilan pada masa pandemi Covid-19. Berdasarkan penelusuran dan pengamatan yang dilakukan oleh peneliti dan salah satu hasil wawancara singkat yang dilakukan terhadap istri yang keluarganya terlilit hutang, ${ }^{3}$ banyak sekali terdapat kekerasan dalam rumah tangga (KDRT) lantaran suami selalu diminta oleh istri untuk membayar hutang. Hal tersebut dikarenakan di desa Sukawangi rata-rata para istri lah yang memiliki hutang.

Dari penjelasan tersebut, peneliti tertarik untuk meneliti bagaimana problematika hutang pada masa pandemi Covid-19 dalam kehidupan masyarakat di desa Sukawangi terhadap keharmonisan keluarga karena sejatinya hutang bersifat paradoks dan diibaratkan

\footnotetext{
${ }^{2}$ Bank plecit merupakan lembaga atau perorangan yang menawarkan jasa pinjaman jangka pendek kepada orang lain dengan jaminan atau tambahan bunga yang relatif tinggi. Mereka akan selalu berusaha untuk menjaga relasi dengan baik kepada para nasabahnya melalui relasi interpersonal atau kultural. Karakteristik yang dimiliki oleh Bank Plecit sama dengan rentenir. Lihat: Heru Nugroho. 2001. Uang, Retenir dan Hutang di Jawa. (Yogyakarta: Pustaka Pelajar). h. 80.

${ }^{3}$ Wawancara dilakukan kepada Ibu R.3 (inisial), beliau merupakan warga desa yang namanya penulis samarkan untuk menghindari penyebaran privasi narasumber. Wawancara dilakukan pada hari jumat, 6 November 2020, pukul 10.15 WIB.
} 
pisau bermata dua. Hal tersebut dikarenakan hutang dapat menjadi penolong bagi sebuah keluarga yang dirundung masalah ekonomi, namun disisi lain hutang juga bisa saja menjerat serta menyengsarakan sebuah keluarga yang berakibat pada konflik terhadap keharmonisan dan keutuhan rumah tangga. Permasalahan pada desa Sukawangi menjadi urgen untuk dibahas, apakah keputusan berhutang yang dilakukan oleh masyarakat di Desa Sukawangi merupakan keputusan yang tepat untuk menyelamatkan keutuhan dan keharmonisan rumah tangga di tengah pandemi Covid-19 atau keputusan berhutang justru menciptakan bumerang bagi keharmonisan dan keutuhan rumah tangga.

\section{METODE PENELITIAN}

Penelitian yang akan dilakukan ini merupakan jenis penelitian lapangan (field research) dengan sifat penelitian deskripstif-analitik, yang memberikan gambaran dan penjabaran mengenai fakta situasi, keadaan dan fenomena sosial yang terjadi di lapangan melalui pendekatan antropologis. Pada metode pengumpulan data dalam penelitian ini akan dilakukan melalui wawancara, obvervasi dan analisis terhadap berbagai dokumentasi, kemudian di interpresetasikan melalui beberapa konsep serta teori ilmiah yang telah ditemukan sebelumnya sehingga dapat mencapai sesuatu pemahaman yang benar.

\section{PEMBAHASAN}

\section{Hutang Keluarga}

Persoalan ekonomi merupakan sebuah faktor yang kerap kali menghantui dalam kehidupan keluarga. Hal tersebut disebakan oleh tingkat kebutuhan yang tinggi dalam menjalani kehidupan sosial sehingga tidak bisa mengkontrol keadaan ekonomi dengan baik. Jika keuangan dalam ekonomi keluarga dikelola dengan tidak baik maka kebutuhan financial keluarga tidak akan terpenuhi dan akan mengalami berbagai hambatan terhadap faktor lain, seperti tekanan spritual, mental, emosional, sosial dan yang lainnya. Dari berbagai faktor tersebut, untuk memenuhi kebutuhan keuangan keluarga maka dilakukan dengan cara berhutang untuk mendapatkan modal usaha dengan tujuan memperbaiki ekonomi dalam keluarga. ${ }^{4}$

Menurut etimologi, hutang ialah uang atau barang yang dipinjam dari seseorang kepada orang lain atau kewajiban untuk membayar kembali atas apa yang diterimanya. ${ }^{5}$

\footnotetext{
4 Syaparuddin. 2014. Pengelolaan Keuangan Keluarga Secara Profesional dalam Menwujudkan Keluarga Sakinah. Al-Risalah; Jurnal Hukum Keluarga Islam. Vol. 1. No. 1. (Juli ). h. 76-91.

${ }^{5}$ Departemen Pendidikan dan Kebudayaan Republik Indonesia. 1999. Kamus Besar Bahasa Indonesia. Edisi II. (Jakrata: Balai Pustaka). h. 1256.
} 
Wahbah az-Zuhaili mengatakan bahwa hutang adalah suatu bentuk penyerahan harta atau benda berharga kepada sesesorang yang tidak terdapat tambahan atau imbahan di dalamnya ketika dilakukan pengembaliannya. ${ }^{6}$

a. Hutang Perspektif Islam

Islam membenarkan dan memperbolehkan hutang karena hutang sendiri merupakan sebuah bukti tolong menolong antar sesama manusia (Hablun minan naas). Hutang ${ }^{7}$ dalam Islam dikatakan dengan istilah qardh yang merupakan suatu upaya memberikan pinjaman kepada seseorang atau orang lain dengan ketentuan syarat pihak yang meminjam harus mengembalikannya kembali sesuai dengan waktu yang disepakati. ${ }^{8}$ Berdasarkan etimologi, hutang sendiri berkonotasi pada uang dan barang yang dipinjamkan dan mempunyai kewajiban untuk membayar kembali apa yang sudah diterima dengan sesuatu yang sama tanpa ada tambahan atau imbalan saat pengembalian. ${ }^{9}$ Sedangkan menurut terminologi, hutang merupakan pemberian harta kepada orang lain untuk diambil manfaatnya setelah itu dikembalikan kembali kepada pemberi hutang sebagai ganti atas apa yang diberikan. ${ }^{10}$ Tujuan dari hutang sendiri sesungguhnya adalah suatu bentuk perilaku saling tolong-menolong yang tetap memerhatikan ketentuan dan persyaratan yang berlaku.

Menurut Kompilasi Hukum Ekonomi Syariah, hutang merupakan suatu penyediaan dana atau tagihan antar lembaga keuangan syariah dengan pihak peminjam untuk melakukan pembayaran atau transaksi secara tunai atau cicilan dalam jangka waktu yang telah disepakti bersama. ${ }^{11}$ Mayoritas ahli fikih mengatakan bahwa segala sesuatu yang bisa dijual belikan secara sah berdasarkan syariat, maka sah pula untuk dihutangkan. Baik itu berupa uang atau barang-barang yang dapat ditakar. ${ }^{12}$

b. Rukun dan Syarat hutang piutang

Rukun dan syarat hutang piutang (qardh) yang harus dipenuhi, antara lain:

\footnotetext{
${ }^{6}$ Wahbah az-Zuhaili. 1998. al-Fiqh al-Islamy Wa 'Adillatuhu. Juz IV. (Bairut: Dar al-Fikr). h. 2915.

${ }^{7}$ Disebutkan dalam Kamus Besar Bahasa Indonesia (KBBI), bahwa hutang merupakan uang atau benda berharga yang dipinjam dari seseoarang atau orang lain yang berkewajiban bagi orang yang meminjam tersebut untuk membayar kembali atas apa yang sudah diterima. Lihat: Departemen Pendidikan Nasional. 2008. Kamus Besar Bahasa Indonesia (KBBI). Edisi Ke-4. (Jakarta: PT Gramedia Pustaka Utama). h. 1540.

${ }^{8}$ Ismail Nawawi. 2012. Fiqh Muamalah Klasih dan Kontemporer Hukum Perjanjian Ekonomi dan Bisnis dan Sosial. (Surabaya: Ghalia Indonesia). h. 177.

9 Yuswalina, 2013. "Hutang-Piutang dalam Perspektif Fiqh Muamalah di Desa Ujung Tanjung Kecamatan Banyuasin III Kabupaten Banyuasin”, Intizar, Vol. 19. No. 2. h. 395-409

${ }^{10}$ Syaikh Shaleh Bin Fauzan al-Fauzan, 2013. Mulkhas Fiqih Panduang Fiqih Lengkap Jilid 2. (Jakarta: Pustaka Ibnu Kasir). h. 99.

${ }^{11}$ Abdul Aziz Ramdansyah, 2016. Esensi Utang dalam Konsep Ekonomi Islam. BISNIS, Vol. 4. No. 1. (Juni). h. 124-135.

12 Abu Sura'i Abdul Hadi. 1993. Bunga Bank Dalam Islam. (Surabaya: al-Ikhlas). h. 127.
} 
1) Pihak yang meminjam (muqtarik) ${ }^{13}$

2) Pihak yang memberikan jasa pinjaman (muqrid $)^{14}$

3) Barang hutang atau yang dihutangkan (muqtarad/ma'qud 'alaih)

4) Sighah (ijab-qabul). ${ }^{16}$

Hukum dalam akad hutang (qardh) yang harus dipenuhi dan diperhatikan dalam transaksi antara pihak peminjam (muqtarik) dan pemberi pinjaman (mukrid) antara lain: ${ }^{17}$

1) Objek akad yaitu dana

2) Tujuannya yaitu 'iwad atau countervalue berupa pinjaman tanpa riba (tambahan)

3) Shighah (ijab dan qabul). ${ }^{18}$

Terdapat beberapa hal yang bisa dijadikan penekanan dalam transaksi untuk berhutang, yaitu mengenai etika sopan satun terkait berhutang, antara lain:

1) Proses hutang piutang harus ditulis dari pihak yang berutang dan terdapat juga sanksi dalam proses tersebut.

2) Meminjam hendaknya dilakukan atas dasar kebutuhan yang mendesak.

3) Pihak yang memberikan hutang hendaknya mempunyai niat untuk membantu pihak yang berhutang.

4) pihak yang berhutang hendaknya untuk mensegerakan membayar hutangnya. ${ }^{19}$

\section{Hak dan Kewajiban pemberi hutang (kreditur) dan penerima hutang (debitur)}

${ }^{13}$ Seseorang yang meminjam (muqtarik) adalah ahliyah mu'amalah, yaitu baligh, berakal, dan tidak mahjur 'alaih (orang yang tidak diperbolehkan oleh syariay untuk mengatur hartanya sendiri). Lihat: Dumairi Nor, Sufandi, dkk,. 2007. Ekonomi Syariah Versi Salaf. (Pasuruan: Pustaka Sidogiri). h. 103.

14 Beberapa syarat yang harus dipenuhi oleh sesorang yang memberikan pinjaman (muqrid), antara lain: (1) ahliyat at-Tabarru' (layak sosial), maksudnya orang yang mempunyai hak penuh dan cakap dalam menggunakan hartanya secara mutlak dan dalam keadaan sadar. (2) iktiyar (tanpa paksaan), dalam memberikan pinjaman kepada orang lain harus berdasarkan keinginan dan kehendak sendiri tanpa ada paksaan dan tekanan dari pihak manapun. Lihat: Dumairi Nor, Sufandi, dkk,. 2007. Ekonomi Syariah Versi Salaf. (Pasuruan: Pustaka Sidogiri). h. 102.

${ }^{15}$ Beberapa persyaratan atas barang yang boleh dijadikan alat hutang, antara lain; (1) suatu benda yang memiliki nilai jual atau berharga, (2) bisa dimiliki, dan (3) bisa diserah terimakan kepada pihak yang berutang. Benda yang tidak tentu adanya dan langka untuk mendapatkannya serta susah untuk mengembalikannya, maka tidak boleh dijadikan objek akad dalam hutang, seperti pemata dan yang sejenisnya. Lihat: Wahbah az-Zuhaili. 2011. Fiqih Islam Wa 'Adillatuhu. Jilid V. (Jakarta: Gema Insani.) h. 337.

${ }^{16}$ Ijab adalah suatu pernyataan dari seseorang (pihak pertama) tentang isi perikatan yang diinginkan sedangkan kabul merupakan pernyataan seseorang (pihak kedua) untuk menerimanya. Lihat: Ahmad Azhar Basyir. 2000. Asas-Asas Hukum Muamalah. (Yogyakarta: VII Press). h. 65.

${ }^{17}$ Ascarya. 2012. Akad dan Prodok Bank Syariah. (Jakrta: Jarawali Press). h. 48.

${ }^{18}$ Sighat suatu bentuk pernyataan yang dinyatakan dalam ijab-qabul sebagai berikut; (1) tujuan akad hutang antara kedua belah pihak harus jelas dan dapat dipahami antara keduannya, (2) ijab dan qabul antara kedua belah pihak harus ada kesesuaian diantara keduanya, dan (3) ijab dan qabul harus ada kehendak dari masingmasing yang bertransaksi tanpa adanya paksan dan keraguan dari keduanya. Lihat: M. Ali Hasan. 2002. Berbagai Macam Transaksi dalam Islam, (Jakarta: PT. Raja Grafindo Persada, 2002), h. 104.

${ }^{19}$ Hendi Suhendi. 2014. Fiqh Muamalah. (Jakarta: Rajawali Press). h. 98. 
Seseorang yang memberi hutang kepada seseorang atau orang lain (kreditur) dan orang yang menerima atau memperoleh hutang dari orang lain (debitur) masing-masing dari mereka memiliki hak dan kewajiban yang harus dipenuhi. Adapun hak dan kewajiban tersebut, antara lain: ${ }^{20}$

a. Hak dan Kewajiban pemberi hutang (kreditur)

1) Hak pemberi hutang (kreditur)

Seseorang yang memberikan hutang (kreditur) mempunyai hak untuk menuntut dan meminta kepada orang yang menerima hutang tersebut (debitur) untuk mengembalikan apa saja yang dihutanginya sesuai dengan perjanjian dan kesepakatan yang telah ditentukan sebelumnya antara kedua pihak (kreditur-debitur)

2) Kewajiban pemberi hutang (kreditur)

Seseorang pemberi hutang (kreditur) mempunyai kewajiban untuk menyerahkan atau memberikan sesuatu yang telah dipinjamkan kepada pihak yang meminjam (debitur) setelah terjadinya perjanjian antara kedua pihak tersebut.

b. Hak dan Kewajiban pemerima hutang (debitur)

1) Hak penerima hutang (debitur)

Seseorang yang menerima hutang atau yang berhutang (debitur) mempunyai hak untuk menerima sesuatu yang menjadi hutangnya dari pihak yang memberikan hutang tersebut (kreditur) berdasarkan kesepatan antara kedua pihak (kreditur-debitur).

2) Kewajiban penerima hutang (debitur)

Seseorang yang menerima hutang atau yang berhutang (debitur) mempunyai kewajiban untuk mengembalikan hutang yang telah dipijam kepada pihak yang meminjamkan (kreditur) berdasarkan ketentuan batas yang telah ditentukan sebelumnya.

\section{Hutang Mayarakat Sukawangi Pada Masa Pandemi Covid-19}

Pada akhir penghujung tahun 2019, merebaknya wabah virus berhasil menggemparkan dunia, yang disinyalir merupakan virus yang baru ditemukan bernama corona virus jenis baru (SARS-CoV-2) di wilayah Wuhan, Tiongkok. ${ }^{21}$ Seluruh dunia tak terkecuali Indonesia sangat merasakan dampak dari virus tersebut. Tahun 2019 akhir, tepatnya ada bulan Desember, diperkirakan terdapat 65 (enam puluh lima) negara telah terjangkit oleh virus tersebut, bahkan

\footnotetext{
${ }^{20}$ Gatot Supramono. 2013. Perjanjian Utang Piutang. (Jakarta: Prenadamedia Group). h. 29.

${ }^{21}$ Yuliana. 2020. Corona Virus Diseases (Covid-19); Sebuah Tinjauan Literatur". Wellness and Healty. Vol. 2. No. 1. (Februari). h. 187-192.
} 
jumlahnya terus mengalami peningkatan. ${ }^{22}$ Akibat dari pandemi virus tersebut. Maka dari itu juga terdapat banyak masyarakat Indonesia yang terdampak dan mengalami kesulitan dari berbagai sektor, termasuk dalam sektor ekonomi.

Berbagai upaya dilakukan oleh pemerintah untuk mengurangi dampak dari wabah virus tersebut, salah satunya adalah dengan meluncurkan beragam jenis bantuan kepada masyarakat. Bantuan yang dimaksud diantaranya adalah bantuan UMKM (untuk membantu UMKM terdampak), bantuan kartu pekerja (untuk mengembangkan kompetensi para pencari kerja), dan bantuan sosial yang lainnya.

Namun, kendati banyak sekali bantuan yang diberikan oleh pemerintah guna meminimalisir besarnya dampak negatif dari wabah Virus Covid-19, pada kenyataannya bantuan tersebut banyak yang tidak mengena langsung pada masyarakat secara tepat. Salah satu penemuan kasus yang terjadi adalah di Jepara sekitar 20 orang yang telah meninggal tetapi tetap menerima bantuan sosial tunai, bahkan ada yang sudah meninggal sejak tahun 2013 pun ternyata tetap mendapatkan bantuan tersebut, serta banyak kasus keluarga yang seharusnya layak dan berhak menerima justru tidak menerima bantuan tersebut. ${ }^{23}$

Salah satu daerah terdampak pandemi Covid-19 dan penerimaan bantuan yang kurang tepat sasaran dirasakan oleh masyarakat di Desa Sukawangi yang terletak di daerah Bekasi Jawa Barat. Permasalahan yang terjadi pada desa tersebut cukup kompleks mulai dari permasalahan ekonomi hingga permasalahan sosial serta kesenjangan sosial. Mayoritas penduduk di sana berprofesi sebagai petani dan pedagang keliling sehingga cukup berat untuk dapat tetap bertahan hidup pada masa pandemi Covid-19 ini bagi masyarakat desa Sukawangi.

Misalnya, Ibu R.5 (inisial) yang merupakan salah satu warga di desa Sukawangi memberikan kesaksiannya dalam sesi wawancara yang dilakukan dengan peneliti. Beliau mengatakan bahwa tidak mendapatkan bantuan berupa sembako dari pemerintah. ${ }^{24}$ Padahal profesinya adalah seorang petani sedangkan suaminya hanyalah pedagang sayur kebun keliling. Keadaan musim yang tidak menentu menjadikan hasil panen tidak maksimal terlebih dengan munculnya pandemi Covid-19 yang berakibat pada gonjangnya keuangan keluarga. Banyaknya tuntutan untuk mencukupi kebutuhan hidup membuat dirinya dan suami memutuskan untuk berhutang kepada salah satu lembaga koperasi desa dan kepada bank

\footnotetext{
${ }^{22}$ Ibid.,

${ }^{23}$ Rolly, Y.R., 2020. PHK dan Setumpuk Masalah. Monadopost.id. Retrieved, (Juli).

${ }^{24}$ Ibu R.5 merupakan warga desa yang namanya penulis samarkan dengan mengunakan inisal untuk menghindari penyebaran privasi narasumber. Wawancara dilakukan pada hari jumat, 6 November 2020, pukul 13.45 WIB. Beliau merupakan salah satu warga Desa Sukawangi, Jawa Barat.
} 
harian dengan bunga yang lumayan besar. Namun menurutnya, keputusannya dan suami untuk berhutang adalah keputusan yang salah. Hanya satu bulan beliau dan suami dapat merasakan hutangnya, selebihnya dia dan suami terus-terusan dirundung masalah lantaran selalu ditagih oleh penagih hutang. Akibat dari hutang dan permasaahan ekonomi, kini dirinya dan suami memutuskan untuk bercerai.

Ketika dilakukan pengamatan di lapangan, peneliti mendapati hanya segelintir masyarakat yang memiliki rumah dengan bangunan permanen. Banyak masyarakat di sana yang tidak memiliki fasilitas kamar mandi pribadi di rumahnya. Banyak yang masih menggunakan kali sebagai kamar mandi darurat "Jamban". Masyarakat yang memiliki sawah pun belum terjamin hidupnya lantaran ketika mereka mengalami musim panen, mereka juga harus bergulat dengan musim. Ketika mereka sedang menghadapi musim yang tidak baik maka pada saat panen pun tetap tidak merasakan perbedaannya, dengan kata lain mereka tetap merasakan dan berada pada lingkaran kesulitan ekonomi. Masyarakat desa Sukawangi sangat jauh jika digambarkan pada posisi masyarakat sejahtera.

Pada hari-hari biasa saja mereka hidup dengan sangat sederhana, ditambah lagi pada saat pandemi seperti sekarang ini, kehidupan mereka sangat prihatin dan sangat kekurangan. Bantuan dari pemerintah yang sejak awal bertarget pada masyarakat kecil yang membutuhkan seperti masyarakat di desa Sukawangi pun tidak seluruhnya mereka dapatkan. Bantuan yang tidak tepat sasaran dan merata pada saat pandemi Covid-19 menjadi pemicu utamanya. Menurut pemaparan dari Ibu R.9, beliau adalah salah satu buruh petani (orang yang menggarap sawah milik orang lain) di desa tersebut, beliau hanya mendapatkan bantuan sembako satu kali selama masa pandemi Covid-19. Sedangkan tetangganya yang memiliki sawah dan bangunan rumahnya tidak permanen rutin mendapatkan bantuan sembako dari pemerintah secara berkala. ${ }^{25}$ Pada saat wawancara dan pengamatan, peneliti juga mendapati 10 orang warga Sukawangi yang mengeluhkan dengan perasaan yang sama seperti yang sedang dirasakan oleh Ibu R.9.

Problematika ekonomi dalam keluarga pada masyarakat Sukawangi saat pandemi Covid-19 menjadikan banyak keluarga di desa tersebut tergiur dan memutuskan untuk meminjam uang ${ }^{26}$ di bermacam tempat untuk memenuhi kebutuhan serta modal usaha.

\footnotetext{
25 Penjelasan tersebut merupakan hasil wawancara yang dilakukan peneliti kepada Ibu R.9 pada 25 November 2020, pukul 13.20 WIB di Karang Getak, Desa Sukawangi.

${ }^{26}$ Kebutuan terhadap uang tidak hanya dipandang dari segi ekonomi saja akan tetapi juga dapat dilihat dari konteks keadaan sosial, politik dan budaya setempat. Pada konteks sosiologi, uang tidak hanya dimaknai
} 
Banyak jasa peminjaman uang baik untuk konsumsi maupun untuk usaha. Jasa pinjaman dana yang terdapat di desa tersebut adalah Mekar, ${ }^{27}$ MBK (Mitra Bisnis Keluarga), ${ }^{28}$ BTPN Syariah, ${ }^{29}$ dan bank harian serta para rentenir (bank plecit). Sebagaimana dilakukan dan dikemukakan oleh salah satu informan yang bernama Ibu R.7 sabagaimana berikut:

"Sebelum pandemi, saya memiliki hutang di koperasi Mekar Alhamdulillah untuk modal usaha. Sekarang sedang susah sekali dan usaha saya sedang macet. Saya tidak memiliki pemasukan sama sekali, untuk makan sehari sekali saja susah. Lalu saya dan suami berunding dan kami memutuskan untuk meminta pembiayaan dana usaha jualan nasi uduk dan gorengan pada BTPN (Bank Tabungan Pensiunan Nasional) Syariah dan Alhamdulillah ada pemasukan untuk keluarga dari usaha saya" 30

Mayoritas keluarga di desa Sukawangi memiliki pinjaman hutang masing-masing satu lembaga peminjam hutang bahkan banyak pula keluarga yang meminjam hutang dilebih dari 1 lembaga pemberi hutang. Sesuai dengan pengamatan peneliti yang diperoleh langsung dilapangan dengan melalui wawancara kepada 30 keluarga dan 5 tokoh masyarakat, problematika keluarga di desa tersebut disebabkan oleh alasan yang hampir sama, yaitu masalah ekonomi. Untuk membenahi perekonomian kebanyakan dari mereka memutuskan untuk merintis usaha atau meneruskan usaha selama masa pandemi Covid-19, keluarga di desa Sukawangi banyak yang memiliki hutang di lebih dari satu lembaga.

Wawancara dilakukan oleh peneliti kepada 30 keluarga di desa Sukawangi, dan dilakukan dengan menggunakan wawancara yang bersifat semi-terstruktur. Daftar pertanyaan dikembangkan berdasarkan literatur terkait. Responden yang sebanyak 30 keluarga tersebut merupakan keluarga yang memiliki hutang hingga saat terjadi pandemi seperti saat ini. Responden yang berhasil dimintai keterangan oleh peneliti keseluruhan merupakan perempuan, karena sebagian besar suami atau laki-laki di desa Sukawangi merupakan petani

sebagai sebuah kebutuhan produksi, distribusi, dan konsumsi serta jasa semata akan tetapi dapat juga dimaknai sebagai suatu yang dapat membangun keadaan sosial masyarakat. Lihat: Hugh Dalziel Duncan. 1997. Sosiologi Uang. Terj. Kiki Alfian. (Yogyakarta: Pustaka Pelajar) h. 27.

27 Mekar (PT Mekar Investama Sampoerna) merupakan sebuah perseroan terbatas yang didirikan untuk meningkatkan kualitas bagi para UMKM di Indonesia. Mekar telah menjangkau semua wilayah Indonesia melalui kerjasama yang dilakukan dengan berbagai koperasi yang memberikan jasa simpan pinjam, bank perkreditan rakyat, dan lembaga keuangan lainnya.

28 MBK merupakan singkatan dari Mitra Bisnis Keluarga prinsip dan cara kerjanya mirip dengan lembaga peminjaman dana lainnya.

${ }^{29}$ BTPN (Bank Tabungan Pensiunan Nasional) Syariah merupakan salah satu bank swasta yang bergerak dibawah naungan dan pantauan OJK dan BI (Bank Indonesia). BTPN Syariah menetapkan prinsip syariah dalam sistem karena tidak melanggar unsur syariah serta menerapkan budaya kerja yang sesuai prinsip syariah. Namun tetap saja margin yang ditetapkan oleh bank tersebut cukup besar yaitu sebesar $30 \%$.

${ }^{30}$ Penjelasan tersebut merupakan hasil wawancara yang dilakukan peneliti kepada Ibu R.7 pada 25 November 2020, pukul 13.45 WIB di Karang Getak, Desa Sukawangi. 
dan pedagang, jadi cukup sulit untuk ditemui saat pagi hingga siang hari. Untuk tujuan kerasiaan terhadap responden, maka profil responden diberikan inisial R.1-R.30.

\section{Tabel 1}

Profil Responden

\begin{tabular}{|c|c|c|c|c|c|c|c|c|}
\hline No. & Inisial & $\begin{array}{c}\text { Jenis } \\
\text { Kelamin }\end{array}$ & Usia & Status & $\begin{array}{l}\text { Pendi } \\
\text { dikan }\end{array}$ & $\begin{array}{c}\text { Hutang } \\
\text { sebelum } \\
\text { Pandemi }\end{array}$ & $\begin{array}{c}\text { Hutang } \\
\text { saat } \\
\text { Pandemi }\end{array}$ & $\begin{array}{l}\text { Keadaan } \\
\text { Keluarga }\end{array}$ \\
\hline 1. & R.1 & Perempuan & 45 & Janda & SD & $\mathrm{Ya}$ & Tidak & Cerai \\
\hline 2. & R.2 & Perempuan & 38 & Janda & SMP & Tidak & $\mathrm{Ya}$ & Cerai \\
\hline 3. & R.3 & Perempuan & 49 & Menikah & SD & Ya & Tidak & $\begin{array}{c}\text { Sering } \\
\text { Konflik }\end{array}$ \\
\hline 4. & R.4 & Perempuan & 35 & Menikah & SMP & $\mathrm{Ya}$ & $\mathrm{Ya}$ & $\begin{array}{c}\text { Sering } \\
\text { Konflik }\end{array}$ \\
\hline 5. & R.5 & Perempuan & 27 & Janda & SMA & $\mathrm{Ya}$ & $\mathrm{Ya}$ & Cerai \\
\hline 6. & R.6 & Perempuan & 45 & Menikah & SD & Tidak & $\mathrm{Ya}$ & $\begin{array}{c}\text { Sering } \\
\text { Konflik }\end{array}$ \\
\hline 7. & R.7 & Perempuan & 50 & Menikah & SMP & $\mathrm{Ya}$ & Tidak & $\begin{array}{c}\text { Terkadang } \\
\text { Konflik } \\
\text { Karena } \\
\text { Hutang }\end{array}$ \\
\hline 8. & R.8 & Perempuan & 39 & Janda & SD & $\mathrm{Ya}$ & $\mathrm{Ya}$ & Cerai \\
\hline 9. & R.9 & Perempuan & 46 & Menikah & SD & Tidak & Ya & $\begin{array}{l}\text { Minim } \\
\text { Konflik } \\
\end{array}$ \\
\hline 10. & N.10 & Perempuan & 48 & Menikah & SD & Tidak & $\mathrm{Ya}$ & $\begin{array}{c}\text { Sering } \\
\text { Konflik }\end{array}$ \\
\hline 11. & R.11 & Perempuan & 51 & Janda & SD & $\mathrm{Ya}$ & $\mathrm{Ya}$ & Cerai \\
\hline 12 & R.12 & Perempuan & 40 & Menikah & SD & $\mathrm{Ya}$ & $\mathrm{Ya}$ & $\begin{array}{c}\text { Sering } \\
\text { Konflik }\end{array}$ \\
\hline 13. & R.13 & Perempuan & 33 & Menikah & SD & $\mathrm{Ya}$ & Tidak & $\begin{array}{c}\text { Sering } \\
\text { Konflik }\end{array}$ \\
\hline 14. & R.14 & Perempuan & 29 & Janda & SMP & Tidak & $\mathrm{Ya}$ & $\begin{array}{c}\text { Sering } \\
\text { Konflik } \\
\end{array}$ \\
\hline 15. & R.15 & Perempuan & 29 & Menikah & SD & Tidak & $\mathrm{Ya}$ & $\begin{array}{c}\text { Sering } \\
\text { Konflik }\end{array}$ \\
\hline 16 & R.16 & Perempuan & 28 & Menikah & SMP & Ya & Ya & $\begin{array}{l}\text { Minim } \\
\text { Konflik }\end{array}$ \\
\hline 17. & R.17 & Perempuan & 30 & Menikah & SMA & $\mathrm{Ya}$ & Tidak & $\begin{array}{c}\text { Sering } \\
\text { Konflik } \\
\end{array}$ \\
\hline 18. & R.18 & Perempuan & 29 & Janda & SD & Ya & Ya & Cerai \\
\hline 19 & R.19 & Perempuan & 29 & Menikah & SMA & Tidak & Ya & $\begin{array}{c}\text { Sering } \\
\text { Konflik }\end{array}$ \\
\hline
\end{tabular}




\begin{tabular}{|c|c|c|c|c|c|c|c|c|}
\hline 20. & R.20 & Perempuan & 33 & Janda & SD & Tidak & $\mathrm{Ya}$ & Cerai \\
\hline 21 & R.21 & Perempuan & 40 & Janda & SD & Tidak & $\mathrm{Ya}$ & Cerai \\
\hline 22. & R. 22 & Perempuan & 40 & Menikah & SD & Ya & Tidak & $\begin{array}{c}\text { Terkadang } \\
\text { Konflik } \\
\text { karena } \\
\text { hutang }\end{array}$ \\
\hline 23 & R.23 & Perempuan & 45 & Menikah & SMP & Tidak & $\mathrm{Ya}$ & $\begin{array}{c}\text { Sering } \\
\text { Konflik }\end{array}$ \\
\hline 24 & R.24 & Perempuan & 50 & Janda & SD & $\mathrm{Ya}$ & $\mathrm{Ya}$ & Cerai \\
\hline 25. & R. 25 & Perempuan & 48 & Menikah & SD & $\mathrm{Ya}$ & Tidak & $\begin{array}{c}\text { Sering } \\
\text { Konflik }\end{array}$ \\
\hline 26 & R.26 & Perempuan & 29 & Menikah & SD & Tidak & $\mathrm{Ya}$ & $\begin{array}{c}\text { Sering } \\
\text { Konflik }\end{array}$ \\
\hline 27. & R.27 & Perempuan & 28 & Menikah & SMP & $\mathrm{Ya}$ & Tidak & $\begin{array}{c}\text { Sering } \\
\text { Konflik }\end{array}$ \\
\hline 28 & R.28 & Perempuan & 28 & Menikah & SD & $\mathrm{Ya}$ & $\mathrm{Ya}$ & $\begin{array}{c}\text { Sering } \\
\text { Konflik }\end{array}$ \\
\hline 29 & R.29 & Perempuan & 30 & Menikah & SMA & $\mathrm{Ya}$ & Tidak & $\begin{array}{c}\text { Terkadang } \\
\text { Konflik } \\
\text { karena } \\
\text { Hutang }\end{array}$ \\
\hline 30. & R.30 & Perempuan & 45 & Menikah & SD & Tidak & $\mathrm{Ya}$ & $\begin{array}{c}\text { Minin } \\
\text { Konflik }\end{array}$ \\
\hline
\end{tabular}

Tabel di atas merupakan hasil dari wawancara yang telah dilakukan peneliti terhadap 30 responden. Dari tabel hasil wawancara tersebut, sebagaimana yang telah peneliti lakukan kepada 30 responden, peneliti mendapati bahwa terdapat 9 kasus perceraian yang terjadi. Responden yang diwawancarai ini mengaku bahwa sebagian besar penyebab pertengkaran dan perceraian dalam rumah tangga adalah karena masalah ekonomi. Permasalahan yang kompleks dari perekonomian keluarga disebabkan adanya hutang yang membayangi keluarga dan menjadi problem serius saat masa pandemi Covid-19 lantaran mereka kesulitan untuk membayar hutang karena minimnya pemasukan.

Satu keluarga dari sembilan keluarga yang bercerai memang tidak berhutang pada masa pandemi Covid-19, namun sisa hutang yang masih ada sebelum masa pandemi Covid19 menjadi masalah keluarga saat pandemi karena dari ketiga puluh responden, terdapat sembilan kelurga yang bercerai karena hutang dan permasalahan ekonomi saat pandemi, maka dalam penelitian ini jumlahnya sebesar $30 \%$.

Selain perceraian, nyatanya konflik dalam rumah tangga pun juga sering dipicu karena adanya hutang keluarga yang menjerat. Terdapat 15 kasus keluarga yang sering mengalami konflik dalam keluarga lantaran hutang-hutang yang mereka miliki. Menurut pengakuan salah 
satu responden yang sering mengalami konflik dalam keluarga, sebagian besar memiliki hutang di lebih dari satu lembaga pemberi hutang. Jika terdapat 15 keluarga yang sering mengalami konflik rumah tangga, artinya jumlahnya sebesar $50 \%$.

Selain itu, sebanyak 12 perempuan yang menjadi korban KDRT secara fisik maupun batin lantaran sang suami merasa terbebani dan terusik karena setiap harinya sang istri selalu meminta uang pembayaran hutang kepada suaminya, namun ada pula istri yang merasa terbebani dengan hutang sang suami yang selaluia bayarkan. Dari 12 perempuan korban KDRT 6 keluarga merupakan bagian dari 9 keluarga yang sudah bercerai, selebihnya memilih untuk masih mempertahankan rumah tangganya. Tidak hanya itu, peneliti juga mendapati banyak sekali keluarga yang sering bertengkar atau cek-cok mengenai permasalahan ekonomi dan hutang dalam keluarga. Keluarga yang terkadang terjadi konflik lantaran hutang sebanyak 3 keluarga atau sebesar 10\%. Selain itu, keluarga yang minim sekali konflik dalam rumah tangga karena hutang adalah sebanyak 3 keluarga atau sebesar $10 \%$.

Ketiga keluarga yang jarang sekali terjadi konflik dan tiga keluarga yang minim sekali konflik nyatanya juga memiliki hutang sebelum atau saat terjadinya pandemi Covid-19. Namun, 6 keluarga tersebut tidak memiliki permasalahan ekonomi ataupun kesulitan ekonomi yang serius maupun kesulitan dalam membayar hutang akibat pandemi ini. Justru terdapat dua keluarga yang sebelum pandemi Covid-19 tidak memiliki hutang, namun saat pandemi justru mereka memutuskan untuk berhutang. Tetapi karena pandai memanfaatkan peluang dan hutang yang mereka pinjam dijadikan modal usaha, maka maka modal tersebut justru membantu di masa pandemi Covid-19. Usaha yang kedua keluarga tersebut adalah usaha air minum dalam galon dan usaha ikan hias.

\section{Diagram 1}

Presentase Keadaan Keluarga Akibat Hutang saat Pandemi

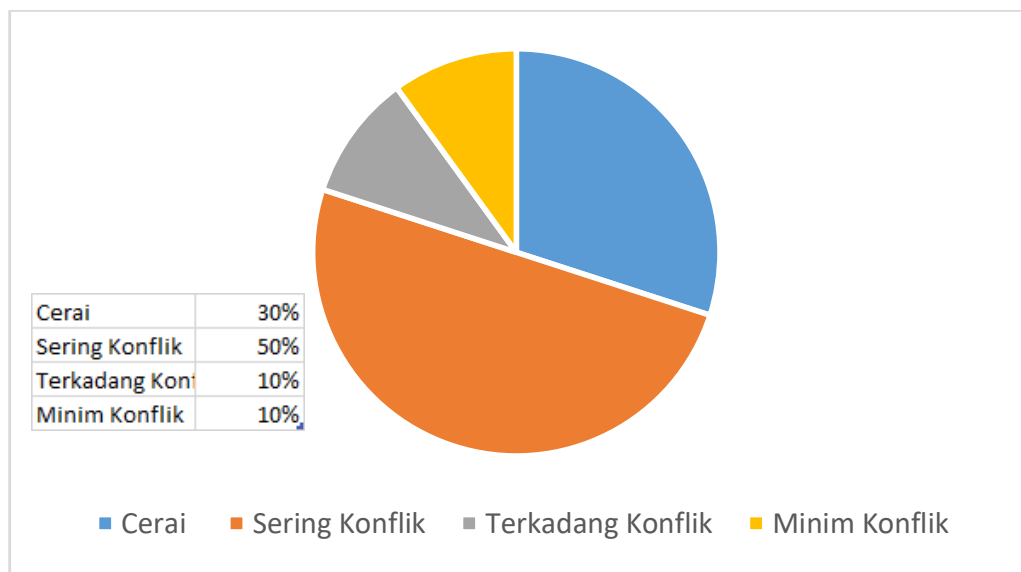


Karena faktor desakan ekonomi, hutang membuat banyak keluarga di desa Sukawangi terlilit dengan hutang dan harus setiap hari berhadapan dengan penagih hutang. Terdapat beberapa keluarga di desa Sukawangi yang mengalami perceraian karena sudah tidak tahan dengan permasalahan hutang yang menjerat keluarganya.

Ibu R.24 merupakan mantan istri dari bapak P.R yang merupakan warga desa Sukawangi. ${ }^{31}$ Beliau mengatakan bahwa memiliki hutang di MBK (Mitra Bisnis Kelurga) untuk modal berjualan ikan segar keliling bersama suaminya. Ia meminjam dana usaha sebelum terjadinya pandemi Covid-19 dan setoran pembayaran hutang setiap minggunya tidak pernah mengalami kendala dan selalu full dalam membayarkan setoran hutang perminggunya. Namun saat terjadi pandemi Covid-19 pendapatan usahanya benar-benar menurun, bahkan pernah di suatu hari dagangannya tidak ada satu orang pun yang membeli. Mantan suami beliau kesal lantaran sering dimintakan uang untuk setoran pembayaran hutang. Sejak saat itu keluarganya tidak lagi harmonis dan saat ini beliau telah resmi bercerai secara agama namun belum secara hukum negara karena kasus perceraiannya belum di selesaikan secara hukum di pengadilan.

Selain itu, terdapat Ibu R.28 yang mengalami KDRT dari laki-laki yang saat ini masih menjadi suaminya. ${ }^{32}$ Beliau adalah seorang Ibu rumah tangga yang memiliki sebuah usaha warung jajanan anak-anak dan terletak di pinggir jalan depan rumahnya. Suaminya adalah bapak K (inisial) yang berprofesi sebagai penjual siomay keliling. Beliau adalah penerima pinjaman usaha dari BTPN (Bank Tabungan Pensiunan Nasional) Syariah. Usaha yang diperoleh dari hasil pinjaman tersebut mengalami penurunan saat pandemi. Namun setoran pembayaran hutangnya yang dilakukan setiap dua minggu sekali tersebut tidak mengalami gangguan. Kemudian, pada saat pandemi Covid-19 beliau memutuskan meminjam dana kepada bank 'plecit' untuk kebutuhan dan tambahan modal usaha. Semenjak saat itulah, kehidupan keluarganya menjadi tidak harmonis. Suaminya sering kali kesal dan mengamuk hingga membanting perabotan rumah tangga saat dimintakan uang untuk membayar hutang kepada bank plecit tersebut. Pada saat itu ia mengaku Bank syariah yang memberikan pinjaman modal memberikan keringanan sebesar setengah angsuran setiap 2 minggu sekali,

\footnotetext{
${ }^{31}$ Penjelasan tersebut merupakan hasil wawancara yang dilakukan peneliti kepada Ibu R.24 pada 25 November 2020, pukul 13.20 WIB di Karang Getak, desa Sukawangi.

32 Pemaparan tersebut merupakan data wawancara yang dilakukan peneliti terhadap Ibu R.28 di Karang Getak, desa Sukawangi pada 26 November 2020 pada pukul 15.30 WIB.
} 
dan saat ini ia hanya memiliki hutang pada bank 'plecit' dan kaluarganya masih dapat terselamatkan dari perceraian.

Pemaparan di atas merupakan beberapa problematika kehidupan rumah tangga yang dialami oleh keluarga di desa Sukawangi. Kasus perceraian dan KDRT serta terganggunya keharmonisan dalam keluarga di desa tersebut rata-rata terjadi lantaran adanya hutang yang melilit kehidupan keluarga di desa Sukawangi. Selain kedua Ibu tersebut, peneliti juga mendapati sekitar 40 kasus perceraian, KDRT, dan menurunnya kualitas keluarga harmonis di desa Sukawangi Jawa Barat.

\section{Dampak Hutang Terhadap Keharmonisan Keluarga di Desa Sukawangi}

Menurut ahli antropologi, keluarga merupakan suatu kesatuan dalam kehidupan sosial masyarakat yang terkecil dan dimiliki oleh manusia. Hal yang demikian, berdasarkan pada kenyataannya bahwa keluarga sendiri adalah satuan kekerabatan yang tinggal bersama dan dilandasi oleh adanya relasi kerjasama ekonomi, memiliki fungsi untuk berkembang biak. ${ }^{33}$ Dalam Islam ${ }^{34}$ dikatakan bahwa keluarga merupakan satu kesatuan hubungan yang membentuk relasi antara laki-laki sebagai suami dan perempuan sebagai istri melalui akad perkawinan yang sah berdasarkan ketentuan yang sudah disyariatkan. ${ }^{35}$

Keluarga sebagai kelompok kecil dalam masyarakat terdiri dari dua bagian, antara lain; Pertama, keluarga inti yang bisa disebut juga dengan istilah "nuclear family", yang merupakan suatu unit dalam kehidupan keluarga yang terdiri dari suami, istri, dan anak. Ada juga yang mengatakan keluarga inti dengan sebutan "conjugal family". Kedua, keluarga besar yang bisa juga disebut dengan istilah "extended family" yang merupakan relasi dari suatu hubungan darah yang terdiri dari beberapa orang, seperti orang tua, anak, kakek, nenek, paman, bibi dan seterusnya. Keluarga besar juga bisa dikatakan sebagai "conguine family". ${ }^{36}$

Terdapat 2 (dua) fungsi dari keluarga yang diantaranya adalah; Pertama, keluarga inti pada fungsinya tidak hanya berfokus pada kesatuan biologis akan tetapi merupakan bagian dari kehidupan sosial masyarakat. Maka tugas keluarga inti selain memelihara anak, juga harus bisa membentuk ide dan sikap sosial yang baik. Kedua, kewajiban keluarga yaitu untuk

\footnotetext{
${ }^{33}$ Wahyu MS. 1986. Ilmu Sosial Dasar. (Surabaya: Usaha Nasional). h. 57.

${ }^{34}$ Islam mendorong untuk membentuk keluarga dan hidup dalam bahtera rumah tangga. Lihat: Ali Yusuf AsSubki. 2010. Fiqh Keluarga, (Jakarta: Amzah). h. 23.

35 Aunur Rahim Faqih. 2001. Bimbingan Dan Konseling dalam Islam. (Yogyakarta: UII Press). h. 70.

${ }^{36}$ Mufidah Ch. 2008. Psikologi Kelurga Islam. (Malang: UIN Malang). h. 40.
} 
meletakkan dan menanamkan dasar-dasar pendidikan, rasa keagamaan, kemauan, kesukaan, dan kecakapan dalam berekonomi, seperti berniaga. ${ }^{37}$

Suatu kenyataan yang tidak bisa disangkal bahwa faktor ekonomi merupakan faktor yang menentukan perilaku sesorang dalam kehidupan sosial masyarakat. Fungsi ekonomi dalam keluarga menjadikan keluarga mandiri dengan mengkonsumsi produk sendiri yang mereka buat. Maka di butuhkan dukungan dan sukungan dana atau keuangan untuk mencukupi kebutuhan produksi keluarga tersebut. Keluarga juga harus bisa memberikan pendidikan ekonomi kepada setiap angota-anggotanya. ${ }^{38}$

Keluarga mempunyai tingkat kematangan spritual dan emosional yang berbeda-beda, maka masalah yang ditimbulkan dalam keluarga juga berbeda-beda. Berbagai faktor yang menyebabkan goyahnya keharmonisan keluarga bahkan berujung pada perceraian. Bebarapa faktor tersebut, yaitu perbedaan cara pandang terhadap agama, budaya, dan faktor ekonomi atau perencanaan keuangan dalam keluarga.

Falah $^{39}$ sudah sepatutnya menjadi tujuan dalam perencanaan keuangan keluarga. Caracara yang bersinggungan dengan maisir, gharar, riba, dan dzalim baik dalam memperoleh pendapatan maupun dalam membelanjakan pendapatan. Cara dalam memperoleh dan membelanjakan haruslah mengutamakan sedakah meski rezeki sedang sempit, serta haruslah menjauhi sikap boros.

Dalam ekonomi Islam falah digunakan sebagai prinsip dasar yaitu segala keputusan dalam perekonomian haruslah mempertimbangkan kebahagiaan dunia dan akhirat. Sebagaimana dijelaskan bahwa setiap kegiatan maupun keputusan yang menyangkut perekonomian haruslah balance antara keuntungan dunia dan akhirat. Dalam dunia ekonomi Islam segala sesuatunya harus dipertimbangkan baik serta buruknya, manfaat serta tidaknya.

Secara lebih singkat pengaturan keuangan dalam keluarga yang cerdas adalah ketika pribahasa “Besar Pasak Dari Pada Tiang” tidak terjadi. Pengeluaran haruslah lebih sedikit dari pada pendapatan. Ketika pengeluaran dapat di atur lebih sedikit dari pada pendapatan maka langkah selanjutnya adalah memikirkan langkah untuk menyimpan dan menginfestasikan kelebihan pendapatan untuk perencanaan masa depan.

\footnotetext{
${ }^{37}$ Rustina. 2014. Keluarga dalam kajian Sosiologi. MUSAWA. Vol. 6. No. 2. (Desember). h. 287-322.

38 Jaladdin Rahmad. 1993. Islam Alternatif Ceramah-Ceramah di Kampus. (Bandung: Mizan). h. 121.

${ }^{39}$ Falah memiliki arti "Kebahagiaan". Kebahagiaan yang dimaksud adalah pencapaian kebahagiaan dunia dan akhirat. Dalam perencanaan keuangan tidak hanya memikirkan kestabilan ekonomi rumah tangga di dunia saja, namun kebahagiaan akhirat dengan perencanaan sedekah dan tidak melanggar hukum syariah.
} 
Begitupun dengan hutang yang harus benar-benar disaring manfaat dan mudharatnya. Wahbah az-Zuhaili mengatakan bahwa hutang adalah suatu penyerahan terhadap harta benda kepada orang lain yang tidak terdapat di dalamnya sebuah imbalan atau tambahan dalam pengembaliannya kembali. ${ }^{40}$ Begitupun yang akan terjadi, seseorang yang berani berhutang pasti harus siap untuk mengembalikan apa yang dihutangnya.

Sesuai dengan problematika rumah tangga yang terjadi pada keluarga di desa Sukawangi, mayoritas tujuan peminjaman uang adalah untuk modal usaha. ${ }^{41}$ Jika dilihat dari segi prinsip, maka hal yang demikian tersebut dapat dibenarkan. Namun, sesuai dengan pengamatan, perhitungan yang kurang akurat justru akan menjadikan hutang menjadi bumerang bagi kehidupan rumah tanga. Meminjam dana usaha pada orang yang kurang tepat juga dapat menjadi banalu dalam keharmonisan rumah tangga. Sedangkan untuk seseorang yang memiliki perhitungan yang akurat dalam mengelola dana hutang maka akan menyelamatkan keluarga di tengah pandemi yang terjadi saat ini.

Contoh keluarga yang ekonominya terselamatkan melalui hutang adalah keluarga Ibu R.7 dan Ibu R.22. ${ }^{42}$ Mereka berhasil memanfaatkan dan menciptakan peluang di tengah krisis seperti saat ini. Mereka mengelola uang pinjaman usaha dari BTPN Syariah untuk modal usaha. Peminjaman tanpa bunga juga sejatinya dapat sedikit menyelamatkan dari jeratan hutang karena sesuai dengan aturan agama.

Kasus hutang yang terjadi pada masyarakat desa Sukawangi memberi gambaran, banyak sekali yang gagal dalam mengelola hutang tersebut, sementara yang hidupnya terselamatkan hanya sebagian keluarga saja. Di desa Sukawangi, berhutang memiliki dambak yang negatif dan bagi sebagian orang berdampak positif. Namun, dampak yang negatif justru terlihat sangat menonjol di desa tersebut dan menjadikan keretakan dalam keharmonisan pada rumah tangga.

\section{KESIMPULAN}

Ketergantungan ekonomi masyarakat desa Sukawangi terhadap hutang pada masa pandemi Covid-19 untuk bisa bertahan hidup mendatangkan masalah dalam kehidupan

\footnotetext{
${ }^{40}$ Wahbah az-Zuhaili. 2011. al-Fiqh....... h. 2915.

41 Pernyataan tersebut merupakan pemaparan dari beberapa narasumber yang diwawancarai peneliti, salah satunya adalah pernyataan dari Ibu R.16. Beliau diwawancarai pada tanggal 28 November 2020, pukul 10.00 WIB.

42 Data diperoleh langsung melalui wawancara yang dilakukan kepada kedua keluarga tersebut di desa Sukawangi pada taggal 27 November, pukul 09.35 WIB.
} 
keluarga. Persoalan hutang menjadi benalu dalam keharmonisan rumah tangga di desa Sukawangi bahkan sampai menjadi sebab berakhirnya sebuah hubungan perkawinan.

Pada hasil pengamatan yang telah dilakukan oleh peneliti, maka ditemukan mengenai dampak dari hutang yang dilakukan oleh masyarakat desa Sukawangi pada masa pandemi Covid-19 terhadap keharmonisan dalam rumah tangga. Pada hasil tersebut, ditemukan bahwa hutang menjadikan retaknya keharmonisan keluarga di desa Sukawangi karena minimnya kemampuan untuk melakukan pengembalian hutang tersebut, apalagi di masa pandemi Covid19. Hanya terdapat beberapa orang saja yang berhasil dan sukses mengelola uang dari hasil hutang dengan melakukan terobosan ekonomi dengan baik dalam memanfaatkan uang hasil dari hutang tersebut sehingga tidak berdampak negatif terhadap keharmonisan keluarga karena dapat membayar atau mengembalikan kembali hutangnya.

\section{DAFTAR PUSTAKA}

al-Fauzan, Syaikh Shaleh Bin Fauzan. 2013. Mulkhas Fiqih PanduangFiqih Lengkap Jilid 2. (Jakarta: Pustaka Ibnu Kasir). h. 99.

Ascarya. 2012. Akad dan Prodok Bank Syariah. Jakarta: Jarawali Press.

az-Zuhaili, Wahbah. 2011. Fiqih Islam Wa 'Adillatuhu. Jilid V. Jakarta: Gema Insani.

Basyir, Ahmad Azhar. 2000. Asas-Asas Hukum Muamalah. Yogyakarta: VII Press.

Ch., Mufidah 2008. Psikologi Kelurga Islam. Malang: UIN Malang.

2008. Psikologi Keluarga Islam Berwawasan Gender. Malang: UIN Press

Departemen Pendidikan dan Kebudayaan Republik Indonesia. 1999. Kamus Besar Bahasa Indonesia. Edisi II. Jakrata: Balai Pustaka.

-------------. 2008. Kamus Besar Bahasa Indonesia (KBBI). Edisi Ke-4. Jakarta: PT Gramedia Pustaka Utama.

Duncan, Hugh Dalziel. 1997. Sosiologi Uang. Terj. Kiki Alfian. Yogyakarta: Pustaka Pelajar. Faqih, Aunur Rahim. 2001. Bimbingan Dan Konseling dalam Islam. Yogyakarta: UII Press.

Hasan, M. Ali. 2002. Berbagai Macam Transaksi dalam Islam, Jakarta: PT. Raja Grafindo Persada.

Nawawi, Ismail Nawawi. 2012. Fiqh Muamalah Klasih dan Kontemporer Hukum Perjanjian Ekonomi dan Bisnis dan Sosial. Surabaya: Ghalia Indonesia.

Nor, Dumairi. Sufandi, dkk,. 2007. Ekonomi Syariah Versi Salaf. Pasuruan: Pustaka Sidogiri.

Nugroho, Heru. 2001. Uang, Retenir dan Hutang di Jawa. Yogyakarta: Pustaka Pelajar.

Rahmad, Jaladdin. 1993. Islam Alternatif Ceramah-Ceramah di Kampus. Bandung: Mizan. 
Ramdansyah, Abdul Aziz. 2016. Esensi Utang dalam Konsep Ekonomi Islam. BISNIS, Vol. 4. No. 1. (Juni).124-135.

Rolly, Y.R., 2020. PHK dan Setumpuk Masalah. Monadopost.id. Retrieved, (Juli).

Rustina. 2014. Keluarga dalam kajian Sosiologi. MUSAWA. Vol. 6. No. 2. (Desember). 287322.

Suhendi, Hendi. 2014. Fiqh Muamalah. Jakarta: Rajawali Press.

Supramono, Gatot. 2013. Perjanjian Utang Piutang. Jakarta: Prenadamedia Group.

Syaparuddin. 2014. Pengelolaan Keuangan Keluarga Secara Profesional dalam Menwujudkan Keluarga Sakinah. Al-Risalah; Jurnal Hukum Keluarga Islam. Vol. 1. No. 1. (Juli). 76-91.

Yuliana. 2020. Corona Virus Diseases (Covid-19); Sebuah Tinjauan Literatur”. Wellness and Healty. Vol. 2. No. 1. (Februari). 187-192.

Yuswalina, 2013. "Hutang-Piutang dalam Perspektif Fiqh Muamalah di Desa Ujung Tanjung Kecamatan Banyuasin III Kabupaten Banyuasin”, Intizar, Vol. 19. No. 2. h. 395-409 